\title{
Message from the Editor: Why Did We Change the Title and Journal Web Site?
}

\author{
Almira R. Shaidulina ${ }^{1 \star}$
}

\author{
${ }^{1}$ Assistant Editor \\ *Corresponding Author: ijese@ijese.com
}

Citation: Shaidulina, A. R. (2021). Message from the editor: Why did we change the title and journal web site? Interdisciplinary Journal of Environmental and Science Education, 17(1), e2239. https://doi.org/10.21601/ijese/9380

International Journal of Environmental and Science Education (IJESE) was founded in 2006 to disseminate high-quality open access research works related to psychological, sociological, economic, and organizational aspects of environmental science, environmental education, and science education, as well as evaluation studies of curriculum development in these fields. From its very first issue, IJESE has proven to be a distinguished scientific platform for experts throughout the World. Shortly after its launch, the journal was included in many respectable indexes such as ERIC and SCOPUS.

Due to a miscommunication between the founders of IJESE and the national ISSN center, the title of the journal was recorded as "International Journal of Environmental Science Education" (details are available at https:// portal.issn.org/resource/ISSN/1306-3065) instead of "International Journal of Environmental and Science Education". Missing word: "and" in the title, generated a discrepancy between the aims of the journal and the title. Additionally, it caused many problems with index centers, such as loss of a considerable number of citations, etc.

In 2019, IJESE was acquired by Veritas Publications, UK, a London-based publisher of scientific journals. Veritas Publications, UK, decided to make the following changes to increase the impact and visibility of the journal:

1) During the transfer of the ISSN record for the journal, the title of the journal was changed to "Interdisciplinary Journal of Environmental and Science Education". This change has cleared the inconsistency for the title. Additionally, the word: "Interdisciplinary" emphasized the interdisciplinary nature inherent in the journal's aims and scope.
2) ijese.com is obtained in addition to ijese.net. Old issues of the journal remain accessible in ijese.net, while new issues of the journal continue to be published in ijese. com.

3) Article processing fee is waived for all articles.

4) All published articles are assigned unique DOI numbers.

5) All incoming manuscripts are subject to screening against plagiarism using a similarity check software.

6) More rigorous editorial criteria are enforced to accept a manuscript for publication. Consequently, readers of IJESE enjoy top quality articles written by authors from diverse geographic locations.

We invite you to visit www.ijese.com for new issues and to submit your manuscripts to IJESE. 